http://dx.doi.org/10.12775/szhf.2015.025

\title{
Korespondencja (wybór)
}

\author{
[411] \\ Do Ludwiga Borowskiego ${ }^{1}$
}

Między 6 a 22 marca 1790

Zapytuje Pan, czym wytłumaczyć jakże często i szybko rozprzestrzeniającą się skłonność do fantazji i jak jej przeciwdziałać. Jedno i drugie przedstawia dla lekarzy naszej psychiki równie trudne do rozwiązania zadanie, jak kilka lat temu dla lekarzy naszych ciał szybko rozprzestrzeniająca się po całym świecie epidemia, nazywana w Wiedniu rosyjskim katarem (Influenza), która dosięgła wielu, ale przeminęła szybko i bez żadnej widocznej przyczyny. Podobieństwo polega na tym, że w jednym i w drugim wypadku lepiej opisujemy choroby, aniżeli pojmujemy przyczyny ich pojawienia się lub możność zapobieżenia im. Chory może uznać się za szczęśliwego, jeśli przepiszemy mu czysto dietetyczny sposób leczenia, rekomendując jako środek na chorobę czystą zimną wodę, resztę zaś pozostawiając przyrodzie.

Wydaje mi się, że wszechobecna pasja czytania okazuje się nie tylko przyczyną (środkiem) rozprzestrzeniania się tej choroby, ale też jadowitą tru-

${ }^{1}$ W liście z 6 marca 1790 r. Borowski zwrócił się do Kanta z prośbą o sąd w sprawie jego pracy Cagliostro, einer der merkwürdigster Abenteuer unseres Jahrhunderts, która ukazała się anonimowo w Królewcu w 1790 roku. Odpowiedź została włączona do napisanej przez Borowskiego biografii Kanta i zatytułowana Über Schwärmerei und die Mittel dagegen. 
cizną (zarazkiem), w który ona przechodzi. Przedstawiciele zamożnych stanów, w tym arystokraci, pretendujący jeśli nie do wyższości, to już na pewno do równego traktowania z tymi, którzy musieli dojść do wiedzy na ciernistej drodze gruntownego studiowania przedmiotu za cenę długotrwałych wysiłków, mogą się cieszyć, spijając z nauk śmietankę, czyli posługując się informatorami i sumarycznymi transkrypcjami; przy tym chcą oni, by zatrzeć rzucającą się w oczy różnicę pomiędzy rozgadaną niewiedzą, a gruntownym poznaniem naukowym, a jest to łatwiejsze, jeśli przyjmiemy za fakty rzeczy niepojęte, pomyślane w perspektywie mglistej możności i zażądamy od gruntownego badacza, by objaśnił, jak przedstawiałby on sobie realizację tego czy innego snu, jakiegoś przeczucia, przedstawienia astrologicznego albo przemiany ołowiu w złoto. Znaczy to, że jeśli tego rodzaju fakty uznamy za dane (zaś spierać się o nie ludzie ci nie pozwalają), nie będzie różnicy pomiędzy byciem a nie byciem uczonym. Takiemu obskurantowi trudno byłoby wytłumaczyć wszystko to, co wie uczony przyrodoznawca, dlatego próbuje on wykazać niewspółmierność wiedzy raczej w łatwy sposób, czyniąc przedmiotem sądu te rzeczy, o których obaj niczego nie wiedzą i których obaj nie pojmują; o których można więc swobodnie wydać dowolny sąd, gdyż w danej dziedzinie również uczony nie zaoferuje niczego lepszego. Stąd ta skłonność rozprzestrzenia się na prostych ludzi.

Przeciwko temu złu znam tylko jeden środek: należy przemienić masową szkolną naukę na wielostronną gruntowną naukę nielicznych i nie tępiąc pasji do czytania, urządzić to tak, ażeby owa nauka kierowała się na właściwy cel; ażeby prawidłowo prowadzonemu uczniowi podobało się tylko to, co rzeczywiście przyniesie mu postęp w nauce danego przedmiotu, a wszystko inne pomijać. Pewien niemiecki lekarz (pan Grimm²) pisze w swych uwagach podróżnika o wszechwiedzy Francuzów, jak to osobliwie nazywa; jednakże jest ona daleka od tego braku smaku, który spotyka się u Niemców. Niemiec tworzy ze swej wszechwiedzy ciężki system, od którego nie jest go łatwo odciągnąć, natomiast we Francji me s m e r y z m nie jest niczym więcej niż modą, która szybko przechodzi.

Zwykły trik, za pośrednictwem którego niewiedza przyjmuje cechy nauki, polega na tym, że fantasta zadaje następujące pytania: czy rozumie Pan na czym polega przyczyna magnetyzmu? albo: czy zna Pan materię wyzwalającą cudowne zjawiska elektryczne? Wykorzystując fakt, że rzeczywiście w tym

${ }^{2}$ J. F. C. Grimm, Bemerkungen eines Reisenden durch Deutschland, Frankreich, England und Holland, Altenburg 1775, t. 1, s. 212 f. 
wypadku także wielki przyrodoznawca równie mało wie o wewnętrznej strukturze materii, jak zadający te pytania nieuk, ten ostatni przypisuje sobie prawo, by na tej podstawie wydawać sądy o możliwych działaniach. Jednakże dla uczonego istotne okazują się te działania, które zawsze może on powtórzyć w eksperymencie, w pełni poddając przedmiot swojej władzy. Nieuk zaś zbiera dane, które mogą być równie efektem aktywności przedmiotu, jak i aktywności oglądającego. Nie chodzi tu więc o rzeczywiste eksperymenty.

$\mathrm{Z}$ takimi wybrykami nic się nie da zrobić. Niech ten animalny magnetyzm magnetyzuje oraz dezorganizuje, ile tylko będzie chciał [ów nieuk] i inni lekkomyślni ludzie; zadanie policji ${ }^{3}$ polega na tym, by wszystko to nie zatruło obrazu dziedziny moralności. Poza tym powinniśmy podążać jedynie drogą badań przyrody poprzez eksperymenty i obserwacje, które czynią poznawalnymi obiekty zewnętrznego zmysłu. Daleko sięgające odżegnanie się przeczy w tym wypadku godności rozumu i sprowadza się do niczego. Do podobnego braku rozumu lepiej odnieść się z milczeniem; podobne zjawiska występują w sferze moralności i szybko przemijają, dając miejsce innym błazeństwom. Jestem itd.

Przełożył Mirosław Żelazny

\footnotetext{
${ }^{3}$ Słowo „policja” nie jest tu użyte we współczesnym znaczeniu. Chodzi o starsze znaczenie wywodzące się od greckiego "polis” i oznaczające władzę państwa w ogóle. W dziedzinie określenia co jest nauką, a co szarlatanerią władzę tę państwo sprawuje poprzez instytucję uniwersytetu (por. Spór fakultetów).
} 